Foreigners and Their Food 
This page intentionally left blank 


\section{Foreigners and Their Food}

Constructing Otherness in Jewish, Christian, and Islamic Law

David M. Freidenreich

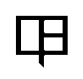

UNIVERSITY OF CALIFORNIA PRESS

Berkeley Los Angeles London 
University of California Press, one of the most distinguished university presses in the United States, enriches lives around the world by advancing scholarship in the humanities, social sciences, and natural sciences. Its activities are supported by the UC Press Foundation and by philanthropic contributions from individuals and institutions. For more information, visit www.ucpress.edu.

\section{University of California Press}

Berkeley and Los Angeles, California

University of California Press, Ltd.

London, England

(C) 2011 by The Regents of the University of California

\section{Library of Congress Cataloging-in-Publication Data}

Freidenreich, David M., 1977-.

Foreigners and their food : constructing otherness in Jewish, Christian, and Islamic law / David M. Freidenreich.

p. $\mathrm{cm}$.

Includes bibliographical references and index.

ISBN 978-0-520-25321-6 (cloth, alk. paper)

1. Food-Religious aspects-Comparative studies. 2. Identification (Religion)-Comparative studies. 3. Religions-Relations. 4. JewsDietary laws. 5. Muslims-Dietary laws. 6. Food-Religious aspectsChristianity. I. Title.

BL65.F65F74 2011

$201^{\prime} .5-\mathrm{dc} 22$

2011006099

Manufactured in the United States of America

$\begin{array}{llllllllll}20 & 19 & 18 & 17 & 16 & 15 & 14 & 13 & 12 & 11\end{array}$

In keeping with its commitment to support environmentally responsible and sustainable printing practices, UC Press has printed this book on Cascades Enviro 100, a 100\% post consumer waste, recycled, de-inked fiber. FSC recycled certified and processed chlorine free. It is acid free, Ecologo certified, and manufactured by BioGas energy. 
To all those with whom I have shared meals and, especially, to Sara 
This page intentionally left blank 